\title{
Front Matter: Volume 9188
}

, "Front Matter: Volume 9188," Proc. SPIE 9188, Optics Education and Outreach III, 918801 (29 September 2014); doi: 10.1117/12.2085337

SPIE Event: SPIE Optical Engineering + Applications, 2014, San Diego, California, SPIE. United States 


\title{
PROCEEDINGS OF SPIE
}

\section{Optics Education and Outreach III}

\author{
G. Groot Gregory \\ Editor
}

18 and 20 August 2014

San Diego, California, United States

Sponsored and Published by

SPIE 
The papers included in this volume were part of the technical conference cited on the cover and title page. Papers were selected and subject to review by the editors and conference program committee. Some conference presentations may not be available for publication. The papers published in these proceedings reflect the work and thoughts of the authors and are published herein as submitted. The publisher is not responsible for the validity of the information or for any outcomes resulting from reliance thereon.

Please use the following format to cite material from this book:

Author(s), "Title of Paper," in Optics Education and Outreach III, edited by G. Groot Gregory, Proceedings of SPIE Vol. 9188 (SPIE, Bellingham, WA, 2014) Article CID Number.

ISSN: 0277-786X

ISBN: 9781628412154

Published by

SPIE

P.O. Box 10, Bellingham, Washington 98227-0010 USA

Telephone +1 3606763290 (Pacific Time) · Fax +1 3606471445

SPIE.org

Copyright $@ 2014$, Society of Photo-Optical Instrumentation Engineers.

Copying of material in this book for internal or personal use, or for the internal or personal use of specific clients, beyond the fair use provisions granted by the U.S. Copyright Law is authorized by SPIE subject to payment of copying fees. The Transactional Reporting Service base fee for this volume is $\$ 18.00$ per article (or portion thereof), which should be paid directly to the Copyright Clearance Center (CCC), 222 Rosewood Drive, Danvers, MA 01923. Payment may also be made electronically through $\mathrm{CCC}$ Online at copyright.com. Other copying for republication, resale, advertising or promotion, or any form of systematic or multiple reproduction of any material in this book is prohibited except with permission in writing from the publisher. The CCC fee code is 0277-786X/14/\$18.00.

Printed in the United States of America.

Publication of record for individual papers is online in the SPIE Digital Library.

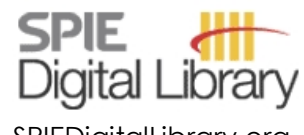

SPIEDigitalLibrary.org

Paper Numbering: Proceedings of SPIE follow an e-First publication model, with papers published first online and then in print and on CD-ROM. Papers are published as they are submitted and meet publication criteria. A unique, consistent, permanent citation identifier (CID) number is assigned to each article at the time of the first publication. Utilization of CIDs allows articles to be fully citable as soon as they are published online, and connects the same identifier to all online, print, and electronic versions of the publication. SPIE uses a six-digit CID article numbering system in which:

- The first four digits correspond to the SPIE volume number.

- The last two digits indicate publication order within the volume using a Base 36 numbering

system employing both numerals and letters. These two-number sets start with 00, 01, 02, 03, 04,

$05,06,07,08,09,0 A, 0 B \ldots$. OZ, followed by 10-1Z, 20-2Z, etc.

The CID Number appears on each page of the manuscript. The complete citation is used on the first page, and an abbreviated version on subsequent pages. Numbers in the index correspond to the last two digits of the six-digit CID Number. 


\title{
Contents
}

\author{
$\checkmark$ Authors \\ vii Conference Committee \\ ix Introduction
}

\section{SESSION 1 OPTICS PROGRAMS}

918802 ETOP: the reference conference in education and training in optics and photonics: an overview of the 12th edition (Invited Paper) [9188-1]

918803 Developing a photonics education program at college level from the ground up [9188-2]

918804 Optical engineering capstone design projects with industry sponsors [9188-3]

918805 NanoJapan: international research experience for undergraduates program: fostering U.S.-Japan research collaborations in terahertz science and technology of nanostructures [9188-4]

918806 Learner-centered teaching in the college science classroom: a practical guide for teaching assistants, instructors, and professors [9188-5]

\section{SESSION 2 OPTICS CURRICULUM}

$918808 \quad$ Illuminating math with optics [9188-7]

$9188 \mathrm{OA}$ Optics and communication technology major of physics undergraduate degree at King Mongkut's Institute of Technology Ladkrabang [9188-9]

9188 OB Digital devices: big challenge in color management [9188-10]

\section{SESSION 3 TECHNOLOGY TO ENHANCE EDUCATION}

9188 OC Color science demonstration kit from open source hardware and software [9188-11]

9188 OD The laser propagation demonstration: a STEM-based outreach project [9188-12]

9188 OE Optics outreach evolves in southern California as OptoBotics begins to link informal to formal curriculum [9188-13]

9188 OF Microcontrollers and optical sensors for education in optics and photonics [9188-14]

9188 OG Increased knowledge transfer by using modern high-speed camera [9188-15] 
$9188 \mathrm{OH} \quad$ Engaging the optics community in the development of informative, accessible resources focusing on careers [9188-16]

9188 Ol SPIE's School Outreach Activity Program (SOAP) by IIT Madras SPIE Student Chapter: a review [9188-17]

9188 OK Color: what, how, and why we see: a workshop for K-12 students and parents [9188-19]

$9188 \mathrm{OL}$ A colorful approach to teaching optics [9188-20]

$91880 \mathrm{M} \quad$ Photonics meet digital art [9188-21]

POSTER SESSION

9188 OP Optics outreach activities with elementary school kids from public education in Mexico [9188-24]

$91880 Q \quad$ Summer school in Kabardino-Balkaria by BMSTU SPIE Student Chapter [9188-25]

9188 OR Outcome based learning of optics in schools [9188-26]

9188 OS Solar powered model vehicle races [9188-27]

9188 OT Easing wave optics understanding through technology [9188-28] 


\section{Authors}

Numbers in the index correspond to the last two digits of the six-digit citation identifier (CID) article numbering system used in Proceedings of SPIE. The first four digits reflect the volume number. Base 36 numbering is employed for the last two digits and indicates the order of articles within the volume. Numbers start with 00, 01, 02, 03, 04, 05, 06, 07, 08, 09, 0A, 0B...0Z, followed by 10-1Z, 20-2Z, etc.

Ben Lakhdar, Zohra, 02

Bunch, Robert M., 04

Buranasiri, Prathan, OA

Calabro, Katherine, OK

Cárdenas-Ortiz, G., OP

Ceballos-Herrera, D., OP

Chernomyrdin, Nikita $\vee ., 0 Q$

Costa, Manuel F. M., 02

Curticapean, Dan, OB, OF, OG, OM

Dominguez, Margaret Z., 06

Donnelly, Judith F., 08, OL

Donnelly, Matthew J., 08

Dreßler, Paul, OB, OF, OG

Fokina, Irina N., $O Q$

Ganesan, A. R., Ol

Garg, Amit, OT

Gavdush, Arsenii A., OQ

Gingras, F., $\mathrm{OH}$

Granieri, Sergio C., 04

Gregory, G. Groot, OK

Haiss, Ulrich, OF

Hyde, Milo W., IV, OD

Israel, Kai, OG, OM

Kachru, Priyanka, OT

Kalikivayi, Lavanya, OI

Kalikivayi, V., Ol

Karasik, Valeriy E., $O Q$

Kono, Junichiro, 05

Lakshminarayanan, Vasudevan, 02

Leisher, Paul O., 04

Magnani, Nancy J., OL

Marciniak, Michael A., OD

Matherly, Cheryl A., 05

Phillips, Sarah R., 05

Poulin-Girard, Anne-Sophie, $\mathrm{OH}$

Raju, M. Esakkimuthu, OR

Ravi, Kumar, OR

Ruiz-Mendoza, J., OP

Sala, Anca L., 03

Sánchez-Guerrero, G., OP

Selvas-Aguilar, R., OP

Serpengüzel, Ali, OS

Silberman, Donn M., OE

Singh, Shatakshi, OT

Spencer, Mark F., OD

Steinbock, Michael J., OD

Thériault, G., $\mathrm{OH}$

Tiwary, Rishabh, OT

Udayakumar, K., 0 l
Vadakkapattu Canthadai, Badrinath, OR

Vauderwange, Oliver, OB, OF, OG

Viera-González, P., OP

Vorndran, Shelby, 06

Wielage, Heinz, OF

Wozniak, Peter, OB, OF, OG

Yılmaz, Nazmi, OS

Yurchenko, Stanislav O., $\mathrm{OQ}$

Zambon, $\mathrm{V} ., \mathrm{OH}$

Zaytsev, Kirill I., OQ

Zghal, Mourad, 02

Zollers, Michael W., OC, OK 
Proc. of SPIE Vol. $9188918801-6$

Downloaded From: https://www.spiedigitallibrary.org/conference-proceedings-of-spie on 26 Apr 2023 Terms of Use: https://www.spiedigitallibrary.org/terms-of-use 


\title{
Conference Committee
}

\author{
Conference Chair
}

G. Groot Gregory, Synopsys, Inc. (United States)

Conference Program Committee

Anna Consortini, Università degli Studi di Firenze (Italy)

Barbara A. Darnell, ScinTech (United States)

Judith Donnelly, Three Rivers Community College (United States)

Nancy J. Magnani, Eastconn (United States)

Brian Monacelli, the Optical Sciences Company (tOSC)

(United States) and Irvine Valley College (United States)

Joseph J. Niemela, The Abdus Salam International Center for

Theoretical Physics (Italy)

Anne-Sophie Poulin-Girard, Université Laval (Canada)

Kathleen B. Robinson, SPIE

José Sasián, College of Optical Sciences, The University of Arizona

(United States)

Donn M. Silberman, PI (Physik Instrumente) L.P. (United States)

Alexander R. Small, California State Polytechnic University, Pomona

(United States)

Cristina Solano, Centro de Investigaciones en Óptica, A.C. (Mexico)

Richard N. Youngworth, Riyo LLC (United States)

María J. Yzuel, Universitat Autònoma de Barcelona (Spain)

\section{Session Chairs}

1 Optics Programs

Judith Donnelly, Three Rivers Community College (United States)

2 Optics Curriculum

Nancy J. Magnani, Eastconn (United States)

3 Technology to Enhance Education

Richard N. Youngworth, Riyo LLC (United States)

4 Promoting STEM

Barbara A. Darnell, ScinTech (United States) 
Proc. of SPIE Vol. $9188918801-8$

Downloaded From: https://www.spiedigitallibrary.org/conference-proceedings-of-spie on 26 Apr 2023 Terms of Use: https://www.spiedigitallibrary.org/terms-of-use 


\section{Introduction}

This year, in San Diego, California, we held the third conference on Optics Education and Outreach. This conference reported on activities from sharing the wonder of science and optics, to the formal processes used to educate the next generation of scientists and engineers.

The conference was well attended and included four oral sessions and one poster session. Audience participation often included the sharing of new ideas with the speakers and attendees. The oral sessions were titled: Optics Programs, Optics Curriculum, Technology to Enhance Education and Promoting STEM. These sessions were held on a single day during the 2014 Optics and Photonics.

The Optics Programs session began with an invited talk from the Education and Training in Optics and Photonics (ETOP) conference, held every other year, and continued with other reports on formal optics training. The Optics Curriculum session explored new way to combine science with other fields in a classroom setting demonstrating the advantages of placing science into real world context. A session titled Technology to Enhance Education covered tools and devices to improve student interest in learning both in and out of the classroom. The final session on Promoting STEM shared outreach activities from creative tools for the dissemination of optical careers in Canada and Europe, to optics with eye examinations providing eye glasses to poor students in India.

My thanks go to those who helped make this conference a success, especially the authors, audience, SPIE staff, and program committee. The authors share the credit for making this conference an unqualified success. The audience built upon this success by being active and asking engaging questions. The SPIE staff ensured that everything ran smoothly before, during, and after the meeting. The program committee provided excellent assistance to ensure the quality of the content, while also presiding over a number of the sessions. It was composed of Anna Consortini, Barbara A. Darnell, Judith Donnelly, Nancy J. Magnani, Brian Monacelli, Joseph J. Niemela, Anne-Sophie Poulin-Girard, Kathleen B. Robinson, José Sasián, Donn M. Silberman, Alexander R. Small, Cristina Solano, Richard N. Youngworth and María J. Yzuel.

The conference will return in two years. If you would like to assist with the 2016 or later conference please contact me. We look forward to seeing you in 2016 !

\section{G. Groot Gregory}


Proc. of SPIE Vol. $9188918801-10$

Downloaded From: https://www.spiedigitallibrary.org/conference-proceedings-of-spie on 26 Apr 2023 Terms of Use: https://www.spiedigitallibrary.org/terms-of-use 